\title{
Long Term Effect of Chemical Fertilizer in Rice-Wheat Cropping System under Irrigated Condition of Kymore Satpura Agro Climatic Zone
}

\author{
S.M. Kurmvanshi*, B.M. Maurya and R.K. Tiwari \\ All India Coordinated Research Project on Farming system, Department of Agronomy, \\ College of Agriculture (J.N.K.V.V.), Rewa (M.P.), India \\ *Corresponding author
}

\begin{abstract}
Keywords
Chemical fertilizer,

Rice-wheat cropping system, Agro climatic zone

Article Info

Accepted:

22 July 2018

Available Online:

10 August 2018 Rewa (M.P.) during $1977-78$ to $2015-16$ to see the changes on soil fertility and productivity of rice-wheat cropping system. The study reveals that application of $120 \mathrm{~kg}$ Nitrogen, $80 \mathrm{Kg} \mathrm{P}_{2} \mathrm{O}_{5} / \mathrm{ha}$ and $40 \mathrm{~kg} \mathrm{~K}_{2} \mathrm{O} / \mathrm{ha}$ maximized the grain yield of rice and wheat without affecting the soil fertility. The grain yield of rice was increased by $32.22 \%$ and wheat by $58.18 \%$ at $120 \mathrm{~kg} \mathrm{~N} / \mathrm{ha}$ as compared to lower doses. The response of phosphorus at $80 \mathrm{~kg} / \mathrm{ha}$ was $18.68 \%$ in rice $29.87 \%$ in wheat. Application of $40 \mathrm{~kg} \mathrm{~K} 2 \mathrm{O} / \mathrm{ha}$ gave $5.54 \%$ higher grain yield of rice and $9.46 \%$ higher grain yield of wheat as compared to no potash application. The grain yield of rice-wheat cropping system was maximized as 120 $\mathrm{kg} \mathrm{N} / \mathrm{ha} 80 \mathrm{~kg} \mathrm{P}_{2} \mathrm{O}_{5} / \mathrm{ha}$ and $40 \mathrm{~kg} \mathrm{k}_{2} \mathrm{O} / \mathrm{ha}$. The net profit was $98.97 \%$ higher due to application of $120 \mathrm{~kg} \mathrm{~N} / \mathrm{ha}, 35.97 \%$ higher at $80 \mathrm{~kg} \mathrm{P}_{2} \mathrm{O}_{5} / \mathrm{ha}$ and $12.03 \%$ at $40 \mathrm{~kg} \mathrm{~K} 2 \mathrm{O} / \mathrm{ha}$ as compared to control or lower doses of chemical fertilizer. The chemical property of soil after 38 years rice-wheat crop cycle reveals that available nitrogen status in soil was almost same as initial status. Phosphorus status showed $9.28 \%$ reduction as compared to initial status. The maximum reduction $41.6 \%$ was observed in available potash as compared to initial status.
\end{abstract}

\section{A B S T R A C T}

A long term manurial experiment on chemical fertilizer in rice-wheat cropping system was taken under All India Coordinated Research Project on Farming System Kuthulia Farm

\section{Introduction}

Rice-wheat rotation is the dominant cropping system in India. Approximately, 10.5 million hectare area comes under this cropping system which contributes $25 \%$ of total food grain in India. About $33 \%$ of India's rice and $42 \%$ of wheat is grown in this rotation. Nearly $65 \%$ of total fertilizer used in the country is applied to rice and wheat crops alone (Yadav and Kumar, 2009). Rice and wheat are the important crops of Madhya Pradesh. Both rice and wheat crops grown in a sequence require high quantity of nutrients to obtain real potential yield (Hedge and Pandey, 1989).

Application of inadequate and unbalanced quantity of fertilizer to these crops not only results low crop yield but also deteriorates the soil properties (Sharma et al., 2003). Degradation in soil health has emerged as a major factor responsible for stagnation in agriculture production. The maintenance of 
good soil health needs balance fertilization which includes the application of NPK in proper amount and form.

Long-term manurial studies reveal that crop productivity is declining even after applying recommended dose of NPK fertilizers (Yadav and Kumar,n 2009). Maurya et al., (2014) reported that application of $120 \mathrm{~kg}$. N/ha, 80 $\mathrm{kg} \mathrm{P}_{2} \mathrm{O}_{5} / \mathrm{ha}$ and $40 \mathrm{~kg} \mathrm{~K}$ O/ha gave maximum grain yield, net profit and benefit cost ratio in rice-wheat cropping system. The wheat equivalent yield was also maximum. The response of nitrogen and phosphorus in rice crop was quadratic while in wheat crop it was linear.

The yield of rice crop showed stagnation while wheat crop starts decline. The soil properties after completion of 38 years of rice -wheat crop cycle showed increase in organic carbon, available $\mathrm{N}$ and phosphorus while potash status in soil showed reduction as compared to initial soil status.

\section{Materials and Methods}

The presented field experiment was taken under, All India Coordinated Research Project on Farming System at Kuthulia Farm of J.N.K.V.V., College of Agriculture Rewa Madhya Pradesh. The present experiment was started in the year 1977-78 and completed in 2015-16. Treatment consisted of three levels of nitrogen i.e. 40,80 and $120 \mathrm{~kg} \mathrm{~N} / \mathrm{ha}$, three levels of phosphorus i.e. 0,40 and $80 \mathrm{~kg} \mathrm{P}_{2} \mathrm{O}_{5}$ /ha and two level of potash i.e. 0 and $80 \mathrm{~kg}$ $\mathrm{K}_{2} \mathrm{O} /$ ha in rice and wheat crop. Total 18 treatment combinations were arranged in Randomized Block Design with four replication. The cropping system was rice followed wheat. The same layout plan was used every year in the same field. The test variety was IR-36 in rice and $\mathrm{WH}-147$ in wheat. The rice crop was transplanted in second to third weeks of July while wheat crop was sown in line in second to third weeds of November during different year (1977 to 2016).

The soil of the experimental field was silty clay loam in texture, neutral in reaction $(\mathrm{pH}$ $7.52)$, medium in organic carbon $(0.54 \%)$, low in available nitrogen $258 \mathrm{~kg} / \mathrm{ha}$, medium in available phosphorus $(12.50 \mathrm{~kg} / \mathrm{ha})$ and high in available potash $\left(500 \mathrm{kgK}_{2} \mathrm{O} / \mathrm{ha}\right)$. The normal rainfall of the tract is $1140 \mathrm{~mm}$. All the recommended package of practices was adopted in rice and wheat as recommended for irrigated condition. The nitrogen dose was given through urea, phosphorus through single super phosphate and potash through muriate of potash.

\section{Results and Discussion}

\section{Effect on rice}

The grain yield of rice in response to continuous application of chemical fertilizer (NPK) has been given in Table 1. After perusal of results it is evident that grain yield of rice was maximum at $120 \mathrm{~kg} \mathrm{~N} / \mathrm{ha}, 80 \mathrm{~kg}$ $\mathrm{P}_{2} \mathrm{O}_{5} / \mathrm{ha}$ and $40 \mathrm{~kg} \mathrm{~K} \mathrm{~K}_{2} \mathrm{O} / \mathrm{ha}$. The response of nitrogen was linear while response of phosphorus was quadratic.

The grain yield of rice was maximum 49.9 q/ha at maximum tested level i.e. $120 \mathrm{~kg} \mathrm{~N} / \mathrm{ha}$ which was $32.22 \%$ higher than lower doses. The response of phosphorus was maximum at $80 \mathrm{~kg} \mathrm{P}_{2} \mathrm{O}_{5}$ but it was at par to $40 \mathrm{~kg} \mathrm{P}_{2} \mathrm{O}_{5} / \mathrm{ha}$. The grain yield of rice was increased by 11.52 $\%$ at $40 \mathrm{~kg} \mathrm{P}_{2} \mathrm{O}_{5} / \mathrm{ha}$ and $18.68 \%$ higher at 80 $\mathrm{kg} \mathrm{P}_{2} \mathrm{O}_{5} / \mathrm{ha}$ as compared to no phosphorus application. Response of potash was only $5.54 \%$ as compared to no potash application. The increase in grain yield due to higher doses to NPK through chemical fertilizer was also reported by Yadav and Kumar (2009) and Anonymous (2012). 
Table.1 Average grain yield (q/ha) of rice under the effect of continuous application of NPK in rice - wheat cropping system

\begin{tabular}{|c|c|c|c|c|c|c|c|c|c|c|}
\hline \multirow[t]{2}{*}{ Treatment } & \multirow{2}{*}{$\begin{array}{l}\text { Average } \\
\text { of } 30 \\
\text { years }\end{array}$} & \multicolumn{9}{|c|}{ Grain yield (q/ha) } \\
\hline & & 2008-09 & 2009-10 & 2010-11 & 2011-12 & 2012-13 & 2013-14 & 2014-15 & 2015-16 & Mean \\
\hline $\mathrm{N}-40$ & 28.64 & 38.96 & 41.91 & 47.00 & 34.66 & 39.36 & 40.34 & - & 3131 & $37.77(00.00)$ \\
\hline N- 80 & 34.32 & 43.91 & 49.61 & 56.00 & 37.04 & 53.16 & 43.26 & - & 34.47 & $43.97(016.41 \%)$ \\
\hline $\mathrm{SEM} \pm$ & - & 0.60 & 0.73 & 0.71 & 0.91 & 1.01 & 0.98 & - & 0.92 & 0.83 \\
\hline $\begin{array}{l}\text { C.D. } \\
(P=0.05\end{array}$ & - & 1.69 & 2.06 & 2.00 & 2.57 & 2.86 & 2.77 & - & 2.60 & 2.35 \\
\hline \multicolumn{11}{|c|}{ Phosphorus levels $\mathrm{P}_{2} \mathrm{O}_{5}$ (kg/ha) } \\
\hline P-0 & 29.18 & 29.18 & 39.08 & 50.80 & 33.99 & 49.09 & 42.03 & - & 33.42 & $40.35(0.00)$ \\
\hline C.D. $P=0.05$ & - & 1.69 & 2.06 & 2.00 & 2.57 & 2.86 & 2.77 & - & 2.60 & 2.35 \\
\hline \multicolumn{11}{|c|}{ Potash levels $\mathrm{K}_{2} \mathrm{O}$ (kg/ha) } \\
\hline $\mathrm{K}-\mathbf{0}$ & 33.31 & 45.77 & 47.64 & 54.10 & 36.52 & 52.17 & 43.93 & - & 33.71 & $43.09(0.00)$ \\
\hline $\mathrm{K}-40$ & 35.69 & 45.77 & 51.19 & 56.95 & 38.67 & 54.41 & 45.43 & - & 35.76 & $45.48(05.54 \%)$ \\
\hline SEM \pm & - & 0.51 & 0.62 & 0.50 & 0.71 & 0.90 & 0.85 & - & 0.75 & 0.69 \\
\hline $\begin{array}{l}\text { C.D. } \\
(P=0.05\end{array}$ & - & 1.44 & 1.75 & 1.41 & 2.02 & 2.55 & 2.40 & - & 2.12 & 1.95 \\
\hline
\end{tabular}

Figures in parentheses are percent increase over lower dose 
Table.2 Average grain yield of wheat (WH-147 q/ha) under the influence of long - term application of NPK in rice- wheat cropping system

\begin{tabular}{|c|c|c|c|c|c|c|c|c|c|c|}
\hline \multirow[t]{2}{*}{ Treatment } & \multirow{2}{*}{$\begin{array}{l}\text { Average } \\
\text { of } 30 \\
\text { years }\end{array}$} & \multicolumn{9}{|c|}{ Grain yield (q/ha) } \\
\hline & & 2008-09 & 2009-10 & 2010-11 & 2011-12 & 2012-13 & 2013-14 & 2014-15 & 2015-16 & Mean \\
\hline \multicolumn{11}{|c|}{ Nitrogen levels $\mathbf{N}$ (kg/ha) } \\
\hline $\mathrm{N}-40$ & 14.94 & 16.46 & 22.03 & 28.07 & 29.12 & 27.00 & 22.69 & 24.04 & 26.03 & $23.41(0.00)$ \\
\hline N- 80 & 21.84 & 22.72 & 28.63 & 32.63 & 33.26 & 35.52 & 32.37 & 30.61 & 31.32 & $29.87(27.59 \%)$ \\
\hline $\begin{array}{l}\text { C.D. } \\
(P=0.05)\end{array}$ & - & 1.42 & 2.21 & 1.91 & 1.92 & 2.60 & 2.86 & 3.11 & 3.68 & 2.46 \\
\hline \multicolumn{11}{|c|}{ Phosphorus levels $\mathrm{P}_{2} \mathrm{O}_{5}$ (kg/ha) } \\
\hline $\mathbf{P}-\mathbf{0}$ & 16.16 & 19.02 & 26.20 & 30.02 & 29.10 & 29.21 & 28.28 & 27.94 & 29.06 & $26.11(00.00)$ \\
\hline P-40 & 21.12 & 25.02 & 28.12 & 34.10 & 32.50 & 34.25 & 31.01 & 30.45 & 32.89 & $29.94(14.66 \%)$ \\
\hline \multicolumn{11}{|c|}{ Potash levels $\mathrm{K}_{2} \mathrm{O}$ (kg/ha) } \\
\hline $\mathrm{K}-\mathbf{0}$ & 20.83 & 23.02 & 27.62 & 32.09 & 31.52 & 32.61 & 29.84 & 28.82 & 31.37 & $28.63(0.00)$ \\
\hline $\mathrm{K}-40$ & 23.96 & 26.17 & 30.00 & 35.22 & 33.50 & 34.27 & 33.05 & 32.38 & 33.57 & $31.34(09.48 \%)$ \\
\hline $\mathrm{SEM} \pm$ & - & 0.42 & 0.49 & 0.53 & 0.57 & 0.75 & 0.90 & 1.07 & 1.50 & 0.53 \\
\hline $\begin{array}{l}\text { C.D. } \\
(P=0.05)\end{array}$ & - & 1.21 & 1.40 & 1.50 & 1.61 & 2.12 & 2.55 & 3.03 & 4.25 & 1.50 \\
\hline
\end{tabular}

Figures in parentheses are percent increase over lower dose 
Table.3 Long term effect of NPK on wheat equivalent yield (q/ha), GMR, NMR and benefit cost ratio in Continuous cropping of rice- wheat

\begin{tabular}{|c|c|c|c|c|c|}
\hline Treatment & $\begin{array}{l}\text { Wheat equivalent } \\
\text { yield (q/ha) }\end{array}$ & $\begin{array}{l}\text { Cost of cultivation } \\
\text { (Rs/ha) }\end{array}$ & $\begin{array}{l}\text { Gross } \quad \text { return } \\
\text { (Rs/ha) }\end{array}$ & Net return (Rs/ha) & B:C ratio \\
\hline \multicolumn{6}{|c|}{ Nitrogen levels $\mathbf{N}$ (kg/ha) } \\
\hline $\mathrm{N}-40$ & 58.91 & 59480 & 92194 & 32714 & 1.55 \\
\hline N- 80 & $71.20(020.86 \%)$ & 60292 & 109988 & $49696(051.91 \%)$ & 1.82 \\
\hline $\mathrm{N}-120$ & $83.97(042.53 \%)$ & 62006 & 127100 & $65094(098.97 \%)$ & 2.04 \\
\hline SEM \pm & - & - & - & - & - \\
\hline C.D. $(P=0.05)$ & - & - & - & - & - \\
\hline \multicolumn{6}{|c|}{ Phosphorus levels $\mathbf{P}_{2} \mathrm{O}_{5}$ (kg/ha) } \\
\hline P-0 & 64.03 & 59280 & 101711 & 42431 & 1.71 \\
\hline $\mathbf{P}-40$ & $72.24(012.82 \%)$ & 60438 & 112235 & $51797(22.07 \%)$ & 1.85 \\
\hline P-80 & $78.92(23.25 \%)$ & 62080 & 120047 & $57967(35.97 \%)$ & 1.93 \\
\hline SEM \pm & - & - & - & - & - \\
\hline C.D. $(P=0.05)$ & - & - & - & - & - \\
\hline \multicolumn{6}{|c|}{ Potash levels $\mathrm{K}_{2} \mathrm{O}$ (kg/ha) } \\
\hline $\mathrm{K}-\mathbf{0}$ & 69.13 & 60297 & 107833 & 47536 & 1.78 \\
\hline $\mathrm{K}-40$ & $74.09(07.17 \%)$ & 60902 & 114157 & $53255(012.03 \%)$ & 1.87 \\
\hline$\overline{\text { SEM } \pm}$ & - & - & - & - & - \\
\hline C.D. $(P=0.05$ & - & - & - & - & - \\
\hline
\end{tabular}

Figures in parentheses are percent increase over lower dose. 
Table.4 Change in soil properties over initial status under the influence of continuous application of NPK in rice- wheat cropping system (after 38 years)

\begin{tabular}{|c|c|c|c|c|c|c|}
\hline Treatment & Soil pH & $\mathrm{EC}(\mathrm{ds} / \mathrm{m})$ & OC (g/kg) & $\begin{array}{l}\text { Available } \\
\text { Nutrients } \\
\text { (kg/ha) }\end{array}$ & & \\
\hline \multicolumn{4}{|c|}{ Nitrogen levels $\mathbf{N}$ (kg/ha) } & $\mathrm{N}$ & $\mathrm{P}$ & $\mathrm{K}$ \\
\hline $\mathbf{N}-40$ & 7.53 & 0.51 & $\begin{array}{c}6.16 \\
(-2.22 \%)\end{array}$ & $\begin{array}{c}195 \\
(-24.40 \%)\end{array}$ & $\begin{array}{c}11.13 \\
(-10.96 \%)\end{array}$ & $\begin{array}{c}292 \\
(-41.60 \%)\end{array}$ \\
\hline N- 80 & 7.57 & 0.50 & $\begin{array}{c}7.10 \\
(+12.69 \%)\end{array}$ & $\begin{array}{c}261 \\
(+1.16 \%)\end{array}$ & $\begin{array}{c}11.12 \\
(-11.04 \%)\end{array}$ & $\begin{array}{c}292 \\
(-41.60)\end{array}$ \\
\hline $\mathrm{N}-120$ & 7.48 & 0.49 & $\begin{array}{c}7.64 \\
(+21.26 \%)\end{array}$ & $\begin{array}{c}273 \\
(+5.81 \%)\end{array}$ & $\begin{array}{c}11.34 \\
(-9.28 \%)\end{array}$ & $\begin{array}{c}297 \\
(-40.60 \%)\end{array}$ \\
\hline \multicolumn{7}{|c|}{ Phosphorus levels $\mathrm{P}_{2} \mathrm{O}_{5}$ (kg/ha) } \\
\hline P-0 & 7.55 & 0.48 & $\begin{array}{c}6.97 \\
(+10.63 \%)\end{array}$ & $\begin{array}{c}255 \\
(-1.16 \%)\end{array}$ & $\begin{array}{c}9.35 \\
(-25.2 \%)\end{array}$ & $\begin{array}{c}292 \\
(-41.60 \%)\end{array}$ \\
\hline $\mathbf{P}-40$ & 7.57 & 0.50 & $\begin{array}{c}6.92 \\
(+9.84 \%)\end{array}$ & $\begin{array}{c}253 \\
(-1093 \%)\end{array}$ & $\begin{array}{c}11.38 \\
(-8.96 \%)\end{array}$ & $\begin{array}{c}293 \\
(-41.40 \%)\end{array}$ \\
\hline $\mathbf{P - 8 0}$ & 7.53 & 0.52 & $\begin{array}{c}7.01 \\
(+11.26 \%)\end{array}$ & $\begin{array}{c}256 \\
(-0.77 \%)\end{array}$ & $\begin{array}{c}12.86 \\
(+2.88 \%)\end{array}$ & $\begin{array}{c}297 \\
(-40.60 \%)\end{array}$ \\
\hline \multicolumn{7}{|c|}{ Potash levels $\mathrm{K}_{2} \mathrm{O}$ (kg/ha) } \\
\hline $\mathrm{K}-\mathbf{0}$ & 7.47 & 0.52 & $\begin{array}{c}7.01 \\
(+11.26 \%)\end{array}$ & $\begin{array}{c}255 \\
(-1.16)\end{array}$ & $\begin{array}{c}11.22 \\
(-10.24 \%)\end{array}$ & $\begin{array}{c}283 \\
(-43.40 \%)\end{array}$ \\
\hline $\mathrm{K}-40$ & 7.52 & 0.53 & $\begin{array}{c}6.92 \\
(9.84 \%)\end{array}$ & $\begin{array}{c}254 \\
(-1.55 \%)\end{array}$ & $\begin{array}{c}11.17 \\
(-10.64 \%)\end{array}$ & $\begin{array}{c}304 \\
(-39.20 \%)\end{array}$ \\
\hline Initial & 7.52 & 0.54 & 6.30 & 258 & 12.50 & 500 \\
\hline
\end{tabular}

Figures in parentheses are percent increase or decrease over initial status. 


\section{Effect on wheat}

The grain yield of wheat has been given in Table 2, reveals that grain yield of wheat was affected significantly under continuous application of chemical fertilizer (NPK). On the basis of 38 years of field experimentation it is clear that wheat yield $37.03 \mathrm{q} / \mathrm{ha}$ was maximum at $120 \mathrm{~kg} \mathrm{~N} / \mathrm{ha}$. The response of phosphorus was maximum $33.91 \mathrm{q} / \mathrm{ha}$ at 80 $\mathrm{kg} \mathrm{P}_{2} \mathrm{O}_{5}$ and response of potash was 31.34 $\mathrm{q} / \mathrm{ha}$ at $40 \mathrm{~kg} \mathrm{~K} \mathrm{~K}_{2} \mathrm{O} / \mathrm{ha}$. The response of nitrogen at $120 \mathrm{~kg} / \mathrm{ha}$ was $58.1 \%$ higher than lower doses of $\mathrm{N}$. The response of phosphorus was $29.87 \%$ at $80 \mathrm{~kg} \mathrm{P}_{2} \mathrm{O}_{5}$ as compared to no phosphorus application. Application of potash @ $40 \mathrm{~kg} \mathrm{~K} 2 \mathrm{O} /$ ha gave $9.4 \%$ higher grain yield of wheat as compared to no potash application. The yield of wheat crop showed declined or stagnated after 38 years of field experimentation. It may be due to development of soil sickness in continuous cropping of rice-wheat. Yadav and Kumar (2009), Gupta et al., (2006) and Maurya et al., (2014) were also reported the yield stagnation in wheat due to development of soil sickness under continuous cropping of rice-wheat system.

\section{Effect on wheat equivalent and monetary return}

The wheat equivalent yield and monetary gain on pooled basis have been given in Table 3 reveals that wheat equivalent yield $83.97 \mathrm{q} / \mathrm{ha}$ was maximum at $120 \mathrm{~kg} \mathrm{~N} /$ ha which was $42.53 \%$ higher as compared to lower tested level of nitrogen. Similar trend in net profit from rice-wheat cropping system was also observed. Response of phosphorus on wheat equivalent yield was maximum $78.92 \mathrm{q} / \mathrm{ha}$ at $80 \mathrm{~kg} \mathrm{P}_{2} \mathrm{O}_{5}$ /ha which was $23.25 \%$ higher as compared to no phosphorus application. Benefit: cost ratio 1.93 was also maximum with net profit of Rs. 57,967/ha at $80 \mathrm{~kg} \mathrm{P}_{2} \mathrm{O}_{5}$ / ha. Application of Potash increased the what equivalent yield by $7.17 \%$, net profit by $12.03 \%$ at $40 \mathrm{~kg} \mathrm{~K}_{2} \mathrm{O} /$ ha in comparison to no potash application. The chemical fertility sustained the yield in rice-wheat cropping system through increased the availability of nutrients if applied in balanced form was also reported by Yadav and Kumar (2009) and Maurya et.al. (2014).

\section{Effect on chemical properties of soil}

The soil sample from 0 to $15 \mathrm{~cm}$ of soil depth were collected and analyzed for PH, electrical conductivity, organic carbon and available NPK after 38 years of field experimentation have been given in Table 4. It is clear from the data that electrical conductivity and soil $\mathrm{pH}$ were unaffected due to continuous application of varying levels of nitrogen, phosphorus and potash in rice and wheat crop. Organic carbon status was increased under varying level of phosphorus and potash and higher levels of nitrogen as compared to initial status. Available nitrogen, phosphorus and potash status were decreased under varying level of nitrogen and phosphorus. The major changes in soil fertility under continuous rice-wheat crop cycle was observed in reduction of available potassium status by more than $41 \%$ under increasing level of nitrogen and Phosphorus and 39.2\% under continuous application of potash $40 \mathrm{~kg}$ $\mathrm{K}_{2} \mathrm{O} / \mathrm{ha}$ in rice and wheat crop each years. The increase in organic carbon and nitrogen in the soil in fertilized plot was due to improved root growth leading to accumulation of more organic residues in rice-wheat cropping system. Such findings were also reported by Yadav and Kumar 2009 and Maurya et al., (2014).

After 38 years of continuous adoption of ricewheat cropping system and application of NPK in rice and wheat it is concluded that application of balance form of $120 \mathrm{~kg} \mathrm{~N}, 80$ $\mathrm{kg} \mathrm{P}_{2} \mathrm{O}_{5}$ and $40 \mathrm{~kg} \mathrm{~K}_{2} \mathrm{O} / \mathrm{ha}$, maximized or 
stabilized the grain yield of rice- wheat cropping system but soil fertility status was decreased. Major reduction in available potash was observed by 11 to $12 \%$ under increasing doses of phosphorus and 39 to $43 \%$ under no application of potash.

\section{References}

Anonymous 2012. Annual Report, All India co-ordinated research project on cropping system JNKVV, College of Agriculture, Rewa (MP)

Gupta, Vikash, Sharma RS and Vishwakarma SK. 2006. Long term effect of integrated nutrient management on yield sustainability and soil fertility of ricewheat cropping system. Indian J. Agron, 51 (3): 161-164.

Hegde, DM and Pandey RK 1989. Rice-wheat system in India. Report of $20^{\text {th }}$ Asian rice farming systems working group meeting held during 2-7 October 1989 at Bogov, Indonesia. pp. 225-227.

Maurya, B.M., Dhakad, S.S. and Tarwariya, M.K. 2014: Long term effect of NPK in rice - wheat cropping system under irrigated conditions of Madhya Pradesh. International Journal of Agricultural Sciences 10 (2): 541-545.

Sharma P, Bali P and Gupta JP. 2003. Long term effect of chemical fertilizer on rice- wheat productivity and fertility of an inceptisol. Ann. Agric. Res., 24 (1): 91-94.

Yadav DS and Kumar Alock 2009. Long term effect of nutrient management on soil health and productivity of rice (Oryza sativa) - wheat (Tiriticum aestivum L.) system. Indian J. Agron., 54 (1): 15-13.

\section{How to cite this article:}

Kurmvanshi, S.M., B.M. Maurya and Tiwari, R.K. 2018. Long Term Effect of Chemical Fertilizer in Rice-Wheat Cropping System under Irrigated Condition of Kymore Satpura Agro Climatic Zone. Int.J.Curr.Microbiol.App.Sci. 7(08): 3918-3925. doi: https://doi.org/10.20546/ijcmas.2018.708.403 